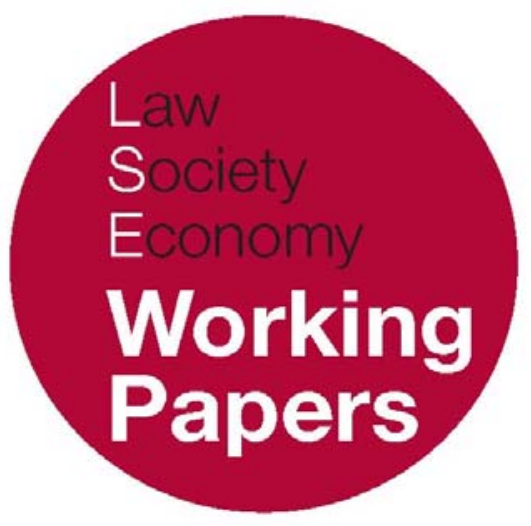

\title{
Proportionality in Perspective
}

\author{
Thomas Poole
}

LSE Law, Society and Economy Working Papers 16/2010

London School of Economics and Political Science

Law Department

This paper can be downloaded without charge from LSE Law, Society and Economy Working Papers at: www.lse.ac.uk/collections/law/wps/wps.htm and the Social Sciences Research Network electronic library at: http://ssrn.com/abstract=1712449.

(C) Thomas Poole. Users may download and/or print one copy to facilitate their private study or for non-commercial research. Users may not engage in further distribution of this material or use it for any profit-making activities or any other form of commercial gain. 


\title{
Proportionality in Perspective
}

\author{
Thomas Poole*
}

\begin{abstract}
This paper questions the received genealogy of proportionality, which traces its origins to continental European sources, especially German administrative law. The paper goes back to Plato and Cicero, two defining writers on law and politics in the classical world. Analysis of their work reveals a richer role for proportionality in visions of public law, and how deeply that idea is embedded in classical conceptions of justice. We see in Plato and Cicero two dimensions particularly worth noting. Proportionality is 'rounded off' in relation to an overarching scale of values - it has a metaphysical or celestial quality. Proportionality also 'reaches out' to identify the relevant political community to which proportionate justice is to apply - which, in Cicero, has a universal or universalising tendency. Returning to the present, the paper argues that the proportionality principle, while certainly attenuated when set against its classical forebears, shares some of the same features. In particular, modern conceptions of proportionality involve, whether explicitly or not, the phenomena of 'rounding off' and 'reaching out', a point that is illustrated by referring to two different attempts to make sense of proportionality in common law judging. One, like Plato, turns inward to the (perceived) structure and values of the state. The other, following Cicero, turns outward in a search for more global standards of justice.
\end{abstract}

\section{INTRODUCTION}

There is a story we tell ourselves about the development of the proportionality principle. It goes something like this. The doctrine of proportionality is of continental European origin. Born in Prussia in the late 18th century as the law was being codified along Rechtsstaat lines, and refined

* Law Department, London School of Economics and Political Science. 
by German administrative courts in the 19 th century, ${ }^{1}$ the principle really took off after the Second World War. Not only did the administrative law principle take constitutional form at that time in Germany, 2 it was also taken up, in imitation of the German model, as a 'meta-principle of judicial governance' by a number of other states and by various international regimes, most notably the European Convention on Human Rights, the European Community, and the World Trade Organization. ${ }^{3}$ In English law, the impetus behind the adoption of the proportionality test came directly from European sources, predominantly the jurisprudence of the European Court of Justice and the European Court of Human Rights (ECtHR). Elsewhere in the common law world, the importation of the principle from continental European sources is less direct but just as clear. In New Zealand's case, for instance, the principle was imported from Canada. ${ }^{5}$ But the Canadians themselves lifted the principle from the ECtHR. ${ }^{6}$ For common lawyers, a recital of this origins story often acts as a prelude to handwringing over the imposition of an 'alien' graft from 'highly systematic' Continental traditions of public law onto an otherwise organic system of common law. ${ }^{7}$

In this paper, I set out to explore the conventional wisdom of proportionality, which if not strictly speaking incorrect is at best a very partial truth. ${ }^{8} \mathrm{I}$ turn first to Plato and then to Cicero, two defining writers on law and politics in the classical world, in order to uncover an older ancestry for proportionality than is generally recognised. Analysis of these writers reveals a richer role for proportionality in visions of public law, and how deeply that idea is embedded in classical conceptions of justice. As I go on to explain, proportionality seems to require both a 'rounding off in relation to an overarching scale of values, typically cast as fundamental and metaphysical, and at the same time a 'reaching out' to identify the relevant political community to which proportionate justice is to apply. Proportionality on the classical account, we shall see, has a tendency to strive towards both the celestial and the universal. Returning to the present, I argue that the proportionality principle applied by courts and discussed by commentators, while

\footnotetext{
1 Article 10(2) of the Prussian General Law (Allgemeines Landrecht) of 1794 authorised the government to exercise police powers in order to ensure public peace, but limited those powers to such measures as were necessary to achieve the chosen goal: 'The police is to take the necessary measures for the maintenance of public peace, security and order.' See M. CohenEliya and I. Porat, 'American Balancing and German Proportionality: The Historical Origins' (2010) 8 International Journal of Constitutional Law 263, 271-273.

2 S. Baer, 'Equality: The Jurisprudence of the German Constitutional Court' (1999) 5 Columbia Journal of European Law 249, 261-264.

3 A. Stone Sweet and M. Jud, 'Proportionality Balancing and Global Constitutionalism' (2008) 47 Columbia Journal of Transnational Law 73, 112.

${ }^{4}$ See eg De Freitas v Permanent Secretary of the Ministry of Agriculture, Fisheries, Lands \& Housing [1999] 1 AC 69 (PC); R (Daly) v Secretary of State for the Home Department [2001] 2 AC 532.

5 See for example Ministry of Transport v Noort [1992] 3 NZLR 260 (CA), 283, per Richardson J; Moonen v Film \& Literature Board of Review [2000] 2 NZLR 9 (CA).

${ }^{6}$ R v Oakes [1986] 1 SCR 103 (SCC). See also eg D. Grimm, 'Proportionality in Canadian and German Constitutional Jurisprudence' (2007) 57 U Toronto LJ 383.

${ }_{7}^{7}$ See eg M. Taggart, 'Proportionality, Deference, Wednesbury' (2008) New Zealand Law Review 423, 438 fn 81: 'The German word for motorway is inserted in brackets because of the strong German influence on the continental European evolution of proportionality and Lord Diplock's attraction to the highly systematic European systems of administrative law.' See also eg S. Boyron, 'Proportionality in English Administrative Law: A Faulty Translation?' (1992) 12 Oxford Journal of Legal Studies 237.

8 The paper only discusses public law. For a history of the concept of proportionality that focuses on penal law from Beccaria and Bentham, see A. Ristroph, 'Proportionality as a Principle of Limited Government' (2005) 55 Duke Law Journal 263.
} 
certainly attenuated when set against its classical forebears, shares some of the same features. In particular, modern conceptions of proportionality involve, whether explicitly nor not, the phenomena of 'rounding off' and 'reaching out', a point that I demonstrate by referring to two different attempts to make sense of proportionality in common law judging. One, like Plato, turns inward to the (perceived) structure and values of the state. The other, following Cicero, turns outward in a search for more global standards of justice.

\section{PLATO, THE SOUL, AND COSMIC ORDER}

For Plato, the goal of human existence was 'becoming like god (bomoiosis theoi) so far as is possible'. ${ }^{9}$ It is god, he said, 'who, par excellence, is the measure of all things for us, rather than a man, as some people claim.' ${ }^{10} \mathrm{He}$ is taking issue here with the relativism of the sophists, and their claim that 'man is the measure of all things' (Protagoras). What, then, does it take to 'become like god'? Whereas 'holiness' does not appear in the list of cardinal virtues that appears in the Republic, it does appear in the later Theaetetus, where Plato says that to become like god is to become 'just and holy, together with wisdom'. Holiness is the virtue that concerns service to god. Since god is essentially good, to serve god is the same thing as to lead a good life. ${ }^{11}$

The relationship between god (the universe or world-soul) and our selves (our soul) is most fully developed in Timaeus, another late dialogue. Here, Plato pursues an analogy between the 'world-soul' and our own soul - the universe supplies, then, the 'larger text' for deciphering the nature of the human soul. The Timaeus offers a 'likely account' of - or metaphor for - the origins of the universe. A demiurge or 'craftsman god', finding 'everything visible in a state of turmoil, moving in a discordant and chaotic manner [...] led it from chaos to order, which he regarded as in all was better.' ${ }^{12}$ In so doing, and wanting 'everything to be good, marred by as little imperfection as possible', he took an eternal and unchanging model (form) as his paradigm. ${ }^{13}$ Note the type of order that has now come into being. There is one universe, not many; 'a single, unique universe, capable, thanks to its perfection, of keeping its own company'. ${ }^{14}$ It is a 'perfectly spherical' universe in which the pre-existing admixture of basic elements (fire, air, earth, water) is now blended in perfect proportion. The previously spasmodic, imbalanced movements of chaos are replaced by ordered motion: 'so he gave it circular movement, by starting it spinning at a constant pace in the same place and within itself.'15 Since what 'is perfectly good can accomplish only what is perfectly beautiful', and given that intelligent products are more beautiful than those lacking intelligence, the universe has intelligence and thus soul, being constructed 'by endowing

\footnotetext{
9 Plato, Theaetetus (in R. Waterfield (ed), London: Penguin, 2004), 176b.

10 Plato, Laws (in T.R. Saunders (ed), London: Penguin, 2004), 716c.

11 D. Sedley, 'The Ideal of Godlikeness' in G. Fine (ed), Plato 2: Ethics, Politics, Religion, and the Soul (Oxford: OUP, 1999), 313-314.

12 Plato, Timaen (in R. Waterfield (ed), Oxford: OUP, 2008), 30a.

13 ibid., 29b.

14 ibid., 34b.

15 ibid., 34a.
} 
soul with intelligence and body with soul'. ${ }^{16}$ The world-soul, Plato tells us, is interwoven with the whole body of the universe and characterised 'by reasoning and harmony'. 'The soul was blended together out of identity, difference and sameness (its three ingredients); the principle of its partition and bonding was rational proportionality; and it circles back on itself.'17 The reason and harmony of the universe is arranged geometrically and consists in (or is expressed by) sets of mathematical ratios. ${ }^{18}$ These ratios also equate to the harmonic structure of Greek music. ${ }^{19}$ The world-soul is at the same time a kind of musical instrument. ${ }^{20}$ Cosmic order is ordered (and harmonious) beauty. Reason 'is the supreme power among the heavenly bodies. ${ }^{21}$

The story of the birth of the universe (and the world-soul) is also the story of the birth of our own soul. The soul was fashioned from what was left of the ingredients the demiurge had used for the world-soul. Charged with finishing the job, the younger gods bound the divine aspect of the soul into the head, made spherical in imitation of the shape of the universe. ${ }^{22}$ The soul thus dwells in the summit of our body, and it rises us up from the earth towards the heavenly region to which we are naturally akin, since we are not soil-bound plants but, properly speaking, creatures rooted in heaven. For it is from heaven, where our souls originally came into existence, that the gods suspended our heads, which are roots, and set our bodies upright. ${ }^{23}$ The body, by contrast, is a creature of necessity, handed over to the head as its servant. Man contains two kinds of (or parts to the) soul. A mortal soul, found within the chest, subject to necessity and the appetitive desires, 'those mindless advisers confidence and fear, and obdurate passion, and gullible hope', and as such 'liable to terrible, but inevitable, experiences'. ${ }^{24}$ And a divine soul, housed within the head, fashioned by the gods with the goal of quelling the uneasy revolutions that occur within us through the application of divinely ordered (or inspired) intelligence. The gods gave us eyes to see the firmament and the intelligence to observe the rational revolutions of the heavens. The purpose of so doing was to enable us to calculate those circular motions correctly and to assimilate our own to the perfect evenness of the god's, and so stabilize the

\footnotetext{
16 ibid., 30b. Also 53b: 'the first thing the god did, when he came to organize the universe, was use shapes and numbers to assign them definite forms; and we can take for granted, as the principal axiom affirmed by us, that the god did not leave them in the condition he found them, but made them as beautiful and as perfect as they could possibly be.' See also Plato, Sophist (in N.P. White (ed), Indianapolis: Hackett, 1993).

17 Plato, n 12 above, 37a. See also T.M. Olshewsky, 'On the Relations of Soul to Body in Plato and Aristotle' (1979) Journal of the History of Pbilosophy 391, 395: 'The mixing of intermediate existence, sameness and difference is described in terms of complicated due proportionality which involves not only number but magnitude.'

18 Including the so-called Golden ratio or Golden mean, hugely influential among Renaissance artists and architects. 'The best bond is the one that most effectively unifies itself and the things it is joining, and nothing does this better than correspondence. For whenever among three numbers (or, for that matter, three solids or three powers) one is a mean, such that as the first number in the series stands to the mean, so the mean stands to the final number of the series (or, conversely, as the final number stands to the mean, so the mean stands to the first), then the mean can also be treated as first or last (or, alternatively, the first and last terms can be treated as means), and so all of them will of necessity turn out to be identical; and since they are all identical, they are all one.' See Timaens, 31c-32a.

${ }_{19}$ There is no mention in Timaeus and subsequent works of any audible harmony of the heavenly bodies. There is harmony in the structure of the world-soul, but no sound. This differs from the Pythagoreans and also from the Myth of Er at 617bc of Plato, Republic (in G.R.F. Ferrari (ed), T. Griffith (trans), Cambridge: CUP, 2000).

20 G. Klosko, The Development of Plato's Political Theory (Oxford: OUP, 2nd ed, 2006), 223: 'Plato attributes great importance to musical forms'.

21 Plato, n 10 above, 967e.

22 Plato, n 12 above, 44d.

23 ibid, 90a.

24 ibid, 69d.
} 
wandering revolutions within us. ${ }^{25}$ 'We should correct the corrupted revolutions in our head concerned with becoming, by learning the harmonies and revolutions of the whole world. 26 This process of ratiocination is, for Plato, more a matter of mathematical calculation than empirical observation: 'it is the eternal mathematical principles of the cyclical celestial motions that we are advised to internalize in our own cerebral revolutions. ${ }^{27}$

\section{PROPORTIONALITY AND THE CONSTITUTION OF THE CITY}

The origins of the universe, and also of our soul, thus represent the triumph of reason over necessity. The persuasive power of intelligence ordered things in such a way that they were geared naturally to strive towards perfection. But what has all this got to do with politics, the city, and its laws? A natural place to start is to slide from the Timaeus to its companion dialogue, the unfinished Critias. ${ }^{28}$ At the centre of that work, in effect a kind of political allegory, lies the recounting of a legend of the interaction between two ancient cities: one, (Old) Athens, embodies the excellence of equilibrium and lasting unity; the other, Atlantis, embodies the corruption that goes with unbalanced (imperial) growth. 'The catastrophe of Atlantis, predictable ever since the description of the island, will be the physiological result of the pronounced imbalance of its constitution. ${ }^{29}$ For Plato, the city was a political living being. It is a particular place; it is also a particular population and a particular constitution; and a particular geographical setting. Hence the wealth of details - geographical, botanical, architectural, and zoological - of the account in Critias.

The city, like the men who inhabit it, has intelligence, a soul. But the connection goes deeper. For there is an isomorphism at work in Plato's treatment of the just state and soul. 'So the just man will not differ at all from the just city, so far as the character of justice is concerned, but will be like it. ${ }^{30}$ The 'individual and the city are identical objects, which differ only in scale and upon which the same letters are inscribed, those of the term "justice". ${ }^{31}$ Justice in respect of the individual is the same as justice in respect of the city. For both, the end to which reason guides them is a harmonious internal order. The excellence (or otherwise) of the city becomes inseparable from the excellence of the thought that lies behind it. And, especially in the later dialogues, Plato assimilates the political constraints attendant upon the ordering of human affairs to the cosmological constraints attendant upon the ordering of physical objects.

\footnotetext{
25 ibid, 47c. A sentiment echoed by Kant in his Critique of Practical Reason (1788, in M. Gregor (ed), Cambridge University Press, Cambridge, 1997), 133: 'Two things fill the mind with ever new and increasing admiration and reverence, the more often and more steadily one reflects on them: the starry heaven above me and the moral law within me. I do not need to search for them and merely conjecture them as though they were veiled in obscurity or in the transcendent region beyond my horizon. I see them clearly before me and connect them immediately with the consciousness of my existence.'

26 Plato, n 12 above, 90d.

27 Sedley, n 11 above, 323.

${ }^{28}$ These two dialogues were designed to form the first two parts of a trilogy - Timaeus-Critias-Hermocrates.

${ }^{29}$ J.F. Pradeau, Plato and the City (Exeter: University of Exeter Press, 2002), 129.

30 Plato, n 19 above, 435b. See also ibid, 434e: 'perhaps by looking at the two [city and man] side by side and rubbing them together, we may make justice blaze out, like fire from two sticks'.

31 Pradeau, n 29 above, 44. See further B. Williams, 'The Analogy of City and Soul in Plato's Republic' in Fine, n 11 above.
} 
The connection between soul, city, and cosmos is most visible in Plato's final work, the Laws. Some find it 'an old man's work', driven by disillusionment and pessimism about the possibility of realising ideals in politics. ${ }^{32}$ Others see in Plato's articulation of his 'second-best' state, ${ }^{33}$ built on top of a vast accumulation of empirical knowledge of comparative law, evidence of 'a more intimate understanding of the materials the statesman has to use, a more persistent effort to work out in its details the political ideal'. ${ }^{34}$ Plato's philosophical method for constructing his near-ideal city in the Laws mirrors his metaphor of the creation of the ordered universe by the demiurge in the Timaeus. In the process of creating the cosmos, the demiurge makes the best it can of things (elements) that happens to be at hand in Chaos. The Lawgiver (or political philosopher) must be like the demiurge in politics, fashioning the laws of the city by sifting through the laws and constitutions of various existing city-states to identify what works best. As in the Republic and the Statesman, the achievement of unity within the city remains the ultimate purpose of politics (while recognising that perfect unity can never be achieved on earth). Whereas written law is absent from the ideal city imagined in the Republic, and the Statesman required the law to preserve the city only in the absence of a knowledgeable governor, ${ }^{35}$ the Laws expects it to construct the city and to bring about its unity. The law has instrumental and constitutive functions: it 'is the proper means used by the legislator to found the city and set it in order'. ${ }^{36}$ Law (nomos) is the instrument of the intellect (nous). It is the 'distribution of reason'37 in the sense that through it, reason determines modes of conduct, and also in the sense that reason effects a distribution (a sharing out of what is due to each individual in the city). ${ }^{38}$

The Laws is prescriptive to the point of obsession about what reason prescribes for the constitution of the city. The city (named Magnesia) described in the Laws is small, rural, and set slightly inland in an averagely fertile place (on Crete) with no immediate neighbours. The city, regarded from the start as a living entity, can thus be virtuous. The territory of the state is divided into 5,040 equal plots of land, each of which is farmed by one family. Citizens are grouped into four classes depending on how wealthy they are. But strict limits are placed on wealth: the richest will never own more than four times the value of one plot of land. ${ }^{39}$ Citizens are also prohibited from owning gold or silver.

The political life of the city takes place in three main bodies: a citizens' assembly; a council elected by all the classes; and (most intriguingly) the 'nocturnal council' (nukterinos sullogos). ${ }^{40}$ So

\footnotetext{
32 Klosko, n 20 above, 217. The mood of disappointment and dispiritedness to be found in the Laws may owe something to the failure of Dion's adventures in Syracuse, in which Plato was involved. But this explanation has also been doubted. Morrow points out, for instance, that the disillusionment predated his experiences in Syracuse. 'Of all the dialogues, the Gorgias, a relatively early one, expresses the deepest pessimism about politics.' G. Morrow, 'The Demiurge in Politics: The Timaeus and the Laws' (1953-1964) 27 Proceedings and Address of the American Philosophical Association 5, 7.

33 Plato, n 10 above, 739a-b: '[T] he right procedure is to describe not only the ideal society but the second and third best too, and then leave it to anyone in charge of founding a community to make a choice between them. So let's follow that procedure now: let's describe the absolutely ideal society, then the second-best, then the third.'

34 Morrow, $\mathrm{n} 32$ above, 7.

35 Plato, Statesman (in J. Annas and R. Waterfield (eds), Cambridge University Press, Cambridge, 1995), $297 \mathrm{~b}$.

36 Pradeau, n 29 above, 142.

${ }^{37}$ Plato, $\mathrm{n} 10$ above, $714 \mathrm{a} 2$.

38 Pradeau, n 29 above, 142.

39 Plato, $n 10$ above, 744a-745a.

${ }^{40}$ In the original text, the nocturnal council is explicitly mentioned only twice. Its name does not carry a formal connotation in the Greek. 'The very name of the body', V. Bradley Lewis argues, 'suggests and informal body unlike the usual political
} 
called because it meets before dawn in order to prepare proceedings for the day to come, this last body is composed of the ten most senior nomophulakes or 'guardians of the law', the Minister of Education and his living predecessors, and priests who have won high distinction. Each of these is to bring with him a younger man of between the ages of 30 and $40 .{ }^{41}$ The Laws is brief in its account of the nocturnal council and its tasks - indeed the body only appears very late in the text. Plato does say, however, that its discussion must centre on the city, the problems of legislation, and anything pertinent learned from other cities. Members 'must be particularly concerned with those studies that promise, if pursued, to further their researches by throwing light on otherwise obscure legislative problems. ${ }^{42}$

The nocturnal council has few formal powers. And yet the Athenian Stranger (Plato's protagonist here) refers to it as the 'anchor' of the whole city, a 'safeguard of the laws' which 'would keep safe everything we wanted it to'. ${ }^{43}$ How this can occur has been a subject of much scholarly debate. ${ }^{44}$ But it seems likely that Plato envisaged that the council might exercise an informal steering and educative role on the other officers of state and, through them, the people. Its influence is to be found in the interstices and looser joints of the legal structure, not contradicting but supplementing the rule of law'. ${ }^{45}$ This indirect but pervasive moral influence stems partly from the council's composition - the men who sit on it hold, after all, many of the city's most senior offices. It also arises from the nature of the council's task. Plato sees that the city he describes requires at least some of its officials to exercise the philosophical and juristic intelligence needed to preserve, expound, and apply the principles on which the laws are based. ${ }^{46}$ The nocturnal council provides the central forum for just this process of reflection. As such, it makes possible just the kind of injection of philosophy into a system of rule that Plato consistently advocated. ${ }^{47}$ 'Where the Republic presents the philosophic regime, the Laws presents a regime with philosophy'. ${ }^{48}$ It is in this way that the nocturnal council represents something akin to the city's (divine) soul. It must, says the Athenian Stranger, 'possess virtue in all its completeness'. ${ }^{49}$ The body, Plato says, 'is to constitute the Intelligence, or Nous, of the state'; 50 and it exists to make the life of the city subject to the intellect.

The politics and sociology of the city are reflected in its topography. Designed according to a geometric pattern, the city is laid out in a series of concentric circles and sections through which the citizens rotate, from their dwelling in one of the twelve designated urban areas to their

institutions of the city. A more accurate, albeit homely, English translation would render nukterinos sullogos as something like "nightly conference" or "nightly meeting".' V.B. Lewis, 'The Nocturnal Council and Platonic Political Philosophy' (1998) 19 History of Political Thought $1,15$.

41 Plato, $\mathrm{n} 10$ above, 951e.

42 ibid, 951e-952a.

43 ibid, 960d \& 961c.

44 See eg G. Morrow, Plato's Cretan City: A Historical Interpretation (Princeton: Princeton University Press, 1960); G. Klosko, 'The Nocturnal Council in Plato's Laws' (1988) 36 Political Studies 74; X. Marquez, 'Knowledge and Law in Plato's Statesman and Laws: A Response to Klosko' (2010) Political Studies 1.

45 Morrow, n 32 above, 19.

46 Morrow, n 44 above, 23.

${ }^{47}$ For instance, Plato argues in his Seventh Epistle that the only solution to the problem of civil strife (stasis) is the injection of philosophy into the regime.

${ }^{48}$ Lewis, n 40 above, 16. Plato, n 19 above, 473d: 'Until philosophers are kings, or the kings and princes of this world have the spirit and power of philosophy, cities will never have rest from their evils.'

${ }^{49}$ Plato, n 10 above, $962 \mathrm{~d} 3$.

${ }^{50}$ Morrow, n 32 above, 17. 
dwelling in one of the twelve rural ones, according to a precise calendar set out in legislation. The movement of the citizenry is designed to have a pragmatic (educative) function, in that it is designed to get citizens to take an interest in the entire city territory. But it also consciously mimics the movement of the heavenly bodies, as described in the Timaeus. 'For the craftsmen who fashion the city, the model is the god who fashioned the world: political demiurgy imitates the cosmological demiurgy and their products are similar. In its own way, the circular city of the Laws is an image of the world's sphere. ${ }^{51}$ The Laws presents the image of the city as a living entity endowed with both soul and body. It is the law's task to achieve peace in the city and harmony in the soul of its citizens. The justice of the city is the same as justice for its citizens, and justice in both cases is patterned on the eternal law of the heavens. Indeed, Plato in the Laws plays on the homonymy of nomos = law, and nomos $=$ chant. The harmonious city is to reflect the unchanging harmony of the spheres.

Proportionality is a pivotal concept within this vision of the city. Justice, for Plato, is ultimately a question of proportional equality. Justice is defined by Socrates in the Republic as a matter of 'rendering to each that which is fitting [for him]'. ${ }^{52}$ In the Laws, Plato describes two concepts of equality: The first sort - arithmetic equality - equates to the simple distribution of equal awards (by lot). But it is the second type, proportionate equality, that he considers 'genuine equality'. He defines it in this way:

The general method I mean is to grant much to the great and less to the less great, adjusting what you give to take account of the real nature of each - specifically, to confer high recognition on great virtue, but when you come to the poorly educated in this respect, to treat them as they deserve. We maintain, in fact, that statesmanship too consists of essentially this - strict justice. 53

Justice, understood as proportionate equality, has distributive as well as corrective dimensions. This is clear from the division of plots and limits on wealth in the Laws. But it also applies to Plato's ideal distribution of authority and social position within the city, which is done in accordance with the natural capacity or fitness of individuals. Justice in the city relates to virtue of the soul. The inquiry into justice as a personal virtue or condition of the soul [is] the internal correlate of justice as right external relations in a community. ${ }^{54}$ Maintaining justice within the city is at least in part about educating citizens in a way that will enable them to maintain the right inner equilibrium to act as good citizens. The Lawgiver's task (in the Laws) is to provide an adequate balance of pleasure and pain by habituating citizens in the right way. Maintaining inner equilibrium involves not just the triumph of reason over the appetitive desires of the body (those 'mindless advisers'), but more specifically that the various parts of body and soul are kept in proportion to each other. What is true of the human soul is also true of the city. Harmony and unity will be produced only if the city is structured in such a way as to keep various classes of people in the right balance. Harmony also requires the maintenance of the right (circular) sort of

51 Pradeau, n 29 above, 159.

52 Plato, n 10 above, 332c.

53 ibid, 757b-c.

${ }^{54}$ F.G. Whelan, 'Justice: Classical and Christian' (1982) 10 Political Theory 435, 441. 
motion - the movements of thoughts within the head, the movement of the citizens, the movements of the heavenly bodies. Harmony has a cosmic - and therefore mathematical specification. Proportion or 'right measure' (taken literally in the late dialogues) in the city can in principle be identified precisely by mathematical (and musical) reflection on the model of the cosmos.

Proportionality flows through all aspects of Plato's theory. Proportion inheres in the soul and in the city and in the universe. ${ }^{5}$ Proportionality is built into the very structure of the cosmos - and by extension of the city and the soul. It is the property or relation which gives order, beauty, and goodness to each. Proportionality, then, is a theological concept. ${ }^{56} \mathrm{We}$ might also observe, from our vantage point, the inegalitarian - even totalitarian ${ }^{57}$ - burden that proportionality shoulders in Plato's theory. For proportionate goodness insists, or so the Athenian Stranger tells us, on 'graded property-classes, to ensure that offices and taxes and grants must be arranged on the basis of what a man is worth. It's not only his personal virtues or his ancestors' that should be considered, or his physical strength and good looks: what he's made of his wealth or poverty should also be taken into account. In short, the citizens must be esteemed and given office, so far as possible, on exactly equal terms of proportionate inequality'. ${ }^{5}$

\section{CICERO, THE REPUBLIC, AND IMPERIAL JUSTICE}

Marcus Tullius Cicero was a lawyer, politician, and statesman active in the last decades of the Roman Republic. 'Saviour of the Republic' when, as consul, he put down the Catiline conspiracy in $63 \mathrm{BC},{ }^{59}$ Cicero went on to write a series of political and philosophical works during the period from $60 \mathrm{BC}$, when he was excluded from active politics with the rise of the first triumvirate. Espousing a version of 'humane conservatism', ${ }^{60}$ Cicero defends in those works the institutions and traditions of the Roman Republic, understood by him as a 'mixed' and ultimately timocratic constitution.

\footnotetext{
55 Note that this vision of the unity of the virtues is not confined to Plato. See A. MacIntyre, After Virtue (London: Duckworth, 2nd ed, 1985), 142: 'The ancestor of one of these sets of answers is Plato, for whom as we have seen the virtues are not merely compatible with each other, but the presence of each requires the presence of all. This strong thesis concerning the unity of the virtues is reiterated both by Aristotle and Aquinas, even though they differ from Plato - and from each other - in a number of important ways. The presupposition which all three share is that there exists a cosmic order which dictates the place of each virtue in a total harmonious scheme of moral life. Truth in the moral sphere consists in the conformity of moral judgment to the order of this scheme.'

56 Plato, n 10 above, 966c: '[W] must never choose as a Guardian of the Laws anyone who is not preternaturally gifted or has not worked hard at theology.'

${ }^{57}$ See C.C.W. Taylor, 'Plato's Totalitarianism' in Fine, n 11 above.

58 Plato, n 10 above, 744b.

${ }^{59}$ In the course of putting down the conspiracy Cicero was instrumental in arranging the extra-legal execution of one of the chief conspirators, Publius Cornelius Lentulus, praetor and former consul. Such action caused resentment in some quarters, and Cicero was sent into exile by the tribune Publius Clodius Pulcher in 58. (Pompey secured his recall in the next year.)

${ }^{60}$ A. Everitt, Cicero (London: John Murray, 2001), 176.
} 
The influence of Plato - and also the Stoics - in Cicero's political philosophy is palpable. ${ }^{61}$ His theory is grounded in broadly similar cosmological and theological roots. Cicero posits an intelligent world soul that brought bodies into being - the providential divine mind (divina mens) that organises the universe and presides over its destiny. This divine mind is understood as instigating a cosmic order based on reason (ratio). This 'unshakeable belief in the rational order of the universe and man' is perhaps the most basic value of Cicero's thought, 'the intellectual underpinning of his other fundamental norms'. ${ }^{62}$ Cicero also assumes that there is a deep connection between cosmic order and political rule. 'To that supreme god who rules the universe nothing (or at least nothing that happens on earth) is more welcome than those companies and communities of people linked together by justice that are called states. ${ }^{63}$ And his understanding of the human psyche bears the stamp of Greek thought. 'For our lusts are set over our thoughts like cruel mistresses, ordering and compelling us to do outlandish things. ${ }^{\text {' } 4}$ Although mathematics and geometry are absent, being unsuited to a Roman audience, much of the language used to express overarching political goals - 'balance', 'harmony', and the like remains the same. Take this passage of purple prose from Cicero's Republic:

Just as with string instruments or pipes or in singers' voices a certain harmony of different sounds must be maintained $[\ldots]$ and as that harmony, though arising from the management of very different notes, produces a pleasing and agreeable sound, so a state, by adjusting the proportions between the highest, lowest, and intermediate classes, as if they were musical notes, achieves harmony. What, in the case of singing, musicians call harmony is, in the state, concord. 65

But what is interesting for our purposes about Cicero is not the way he domesticated Greek philosophy into late Republican Rome. I want to concentrate instead on two distinctive (and distinctively Roman) aspects of his thought. The first such aspect is the central role played by law in his political thought. His theory, centring on a powerful account of natural law, is much more obviously juridical than the Greek works that influenced him. The second aspect is the tension in Cicero's work over the appropriate locus of justice. For Plato (and Aristotle), justice was a property of the city. The matter is for Cicero, as we shall see, rather less clear-cut. An empirically grounded and specifically Roman notion of constitutional justice pulls against a Stoicinfluenced notion of cosmopolitan justice. These two aspects will be examined in turn.

For Plato, as we have seen, the connection between reason and law is less than umbilical. Law made a rather late arrival on the scene - the Laws was Plato's last dialogue - and even then was understood more as the product rather than the instantiation of reason. Justice, reason, and

\footnotetext{
${ }^{61}$ Morrow, n 32 above, 20: 'We might even plausibly argue that Plato's Laws, through the Stoics and Cicero, was an important factor in the rise of [a] class of professional jurists in Rome.' Indeed, as well as studying Greek thought in Rome, Cicero as a young man spent a number of years in Greece studying rhetoric and philosophy. See eg Cicero, On Duties (in M.T. Griffin and E.M. Atkins (eds), Cambridge: Cambridge University Press, 1991), II.155: 'I myself, whatever assistance I have given the republic, if I have given any, came to public life trained and equipped by my [philosophy] teachers and their teachings.'

${ }^{62}$ N. Wood, Cicero's Social and Political Thought (Berkeley: University of California Press, 1988), 70.

${ }_{63}$ Plato, n 19 above, VI, 13.

64 ibid, VI, 1.

65 ibid, II, 69.
} 
law are more closely related in Cicero. We are 'born for justice', Cicero says in the Laws, ${ }^{66}$ which means that we are born also to law. Law is 'the highest reason, inherent in nature [...] When that reason is fully formed and completed in the human mind, it, too, is law' ${ }^{67}$ There are a number of points to be made about this conception. First, law is understood as the mark of the divine mind on all things. It is the essence of nature - God rules the universe by means of the law of nature. 'Law prescribes and prohibits in regard to the functioning of all things. Law is the edict of nature and as such the highest expression of the supreme rationality and authority.' ${ }^{68}$ Second, the law as understood by Cicero is not necessarily positive. He refers, for instance, to 'that highest law which came into being countless centuries before any law was written down or any state was even founded'. ${ }^{69}$ Third, law inheres within the mind of the individual as much as the institutions and practice of the city. One implication of this is that an unjust law (or command) is not properly regarded as law at all. Fourth, law - law properly so called, natural law - is to be considered divine (or at least divinely inspired). 'Since, then, there is nothing better than reason, and reason is present in both man and God, there is a primordial partnership in reason between man and God. But those who share reason also share right reason; and since that is law, we men must also be thought of as partners with the gods in law. ${ }^{70}$

But where does Cicero go with this and what does it have to do with proportionality? Cicero makes a subtle distinction between two forms of justice or fairness. The first form, which he calls aequitas, is the simpler form, denoting something like formal legal equality. The second form, called aequabilitas, Cicero reserves for a higher form of fairness - impartial, unvarying, consistent, evenly distributed. ${ }^{71}$ It refers to that 'equality which gives to each according to his merits, his dignity and authority'. ${ }^{72}$ Natural law (or reason) dictates a higher form of justice which prescribes a particular constitutional structure and a certain distribution of goods (especially property). At its core lies the idea of proportionate equality, the (aristocratic) principle that more is owed to the superior, here defined principally in terms of birth and wealth, and less to the inferior. Each individual is duty-bound under the law of nature to render 'to each his due' in reference to life, property, promises, and benevolence. What is due to each depends upon the worth of each. The first duty of the republic becomes to safeguard the rights of private property, ${ }^{73}$ rights which acquire through the theory a 'tincture of natural sanction' ${ }^{74}$ Cicero even goes so far as to argue that cities grew up so that their citizens might have protection of their possessions. ${ }^{75}$ Cicero, defender of the inherited privileges of the senatorial class, thus deployed a natural law framework as a means of advancing 'the oligarchic element in the Res Publica, in

66 ibid, I.28.

67 ibid, I.18-19.

68 Wood, n 62 above, 70-71.

${ }^{69}$ Plato, $\mathrm{n} 10$ above, I, 19.

70 Plato, n 10 above, I, 23.

${ }^{71}$ E. Fantham, 'Aequabilitas in Cicero’s Political Theory, and the Greek Tradition of Proportional Justice' (1973) 23 Classical Quarterly 285.

${ }^{72}$ C. Nicolet, 'Cicéron, Platon et Le Vote Secret' 19 Historia 39, 64 (my translation).

${ }^{73}$ See J.M. Carter, 'Cicero: Politics and Philosophy' in J.R.C. Martyn (ed), Cicero and Virgil: Studies in Honour of Harold Hunt (Amsterdam: Adolf M. Hakkert, 1972).

74 Wood, n 62 above, 76.

75 In Cicero, n 61 above. 
which financial superiority was recognized as a claim to greater political rights, and justice was seen in the proportional representation of political power to wealth'. ${ }^{76}$

But what, for Cicero, is the relevant locus or political context in which the framework of natural law, reason, and proportionate equality are meant to operate? The equivalent question in Plato's case would be straightforward to answer. ${ }^{77}$ Justice properly so called is exercised between free and equal citizens of the same city - 'by and large the scope of justice is defined by the boundaries of this particular polis. ${ }^{78}$ Cicero's position is less clear cut. On one hand, Cicero in the Republic makes a detailed, historically informed analysis of the Roman (Republican) constitution. He prefers the concrete and specific, he says, to the imaginary communities of Plato. ${ }^{79}$ And he is quite clear that states vary in terms of their moral excellence - he echoes, for instance, Plato's prejudice against coastal cities as prone to corruption and decay. ${ }^{80}$ The Roman constitution is examined precisely because it is different from - and better than - the constitutions of other states. It might appear from this approach, then, that the relevant context for justice is the state. Elsewhere in the Republic, however, Cicero is adamant that natural law evades the boundaries of the state. As right reason, law is in harmony with nature. There is not one law for Rome and another for Athens; 'all peoples at all times will be embraced by a single and eternal and unchangeable law.' 81 This cosmopolitan dimension is even more apparent in the discussion of natural law in the Laws, where the Stoic influence is most pronounced. The whole universe, obeying the same celestial system, the divine mind, must be understood as 'a single community shared by gods and men'. ${ }^{82}$

And when the mind examines the heavens, the earth, the sea, and the nature of all things, and perceives where those things have come from and to where they will return [...] and realizes that it itself is not a resident in some particular locality surrounded by man-made walls, but a citizen of the whole world as though it were a single city; then, in the majesty of these surroundings, in this contemplation and comprehension of nature, great God! how well it will know itself[.] ${ }^{83}$

There is something glorious, no doubt, about this vision of global justice. But things are more complex than they first appear. What we are really witnessing here is an internal Roman disquisition on the 'burden of empire', almost certainly the first of its kind. Rome had expanded massively during Cicero's lifetime, its imperium stretching outwards from its base on the Italian peninsula, Sicily, and nearer Spain to embrace more of north Africa, the near East, most of Spain, and Gaul. In a sense, then, the Republic sought to justify the ways of Rome to man. It aimed to show how 'Roman conquest and Roman government are justified and sanctified by the

\footnotetext{
${ }^{76}$ Fantham, n 71 above, 290.

77 Although Socrates was quoted by Plutarch as saying, 'I am not an Athenian or Greek, but a citizen of the whole world.' Plutarch, Morals, Part VII, 'Of Banishment, Or Flying One's Country', 5.

78 A. MacIntyre, Whose Justice? Which Rationality? (London: Duckworth, 1988), 146.

79 Plato, n 19 above, II, 3.

80 ibid, II, 7.

81 Plato, n 19 above, III, 33.

82 Plato, n 10 above, I, 23.

83 ibid, I, 60 (my emphasis).
} 
natural law of the universe'. ${ }^{84}$ Since, for Cicero, the Roman constitution most closely approaches the perfection of the mixed constitution (itself reflecting the barmonia and concordia of the cosmos), Rome is clearly deserving of eternal world rule. The 'Dream of Scipio', with which the Republic closes, describes the (entirely fictional) dream vision of the Roman general Scipio Aemilianus two years before he destroyed Carthage, Rome's long-standing rival. In imagery redolent of the Timaeus, Cicero describes how the cosmos becomes the reward for the souls of statesmen (like Scipio's grandfather by adoption, the conqueror of Hannibal, and natural father, conqueror of Macedonia) and those who 'respect justice and do [their] duty', honouring their ancestors and even more their country. ${ }^{85}$

This reading of Cicero helps square the circle between the statist and globalist aspects of Cicero's account of justice. On Cicero's account the global and the local become one, in a certain sense. Not only does Rome become the epitome of good government, the state most clearly designed by the divine architect to represent divine order on earth. But also (and for the same reason) the rule of Rome over the whole world becomes a matter of divine sanction. In both these senses, then, 'Rome is the cosmos. ${ }^{86}$ Cicero may have been the first Roman thinker to think systematically about the imperial dimension of Roman law and politics. But this Ciceronian vision of a divinely sanctioned universal Roman order became a familiar political and rhetorical refrain by the early years of the Principate, as the limes of empire stretched still further. In this era, the force of the divina mens became bound up with the figure of the emperor. Pliny the Elder writes of Rome as being chosen by providence 'to make heaven itself more glorious, to unite scattered empires [...] to give mankind bumanitas and in a word become throughout the world the single fatherland of all peoples' ${ }^{87}$ Vitrivius, in his classic book on architecture, hymns the built reality of Roman imperium, writing in the preface about the 'divine mind and power' of its dedicatee, Augustus Caesar, who has seized command of the world. ${ }^{8} 8$

But, at least in its original Ciceronian formulation, the idea of Roman justice being divinely sanctioned had a sting in its tail. The surface gloss about Roman justice being the embodiment of the proportionate equality of natural (divine) law cannot hide the fact that even Roman rule is, in the end, all too human. Beneath the triumphal blaze, you can just detect a faint note of decay. Cicero's own generation by no means escapes responsibility for presiding over a declining, if still expanding, order. We, Cicero charges his fellow citizens, 'after inheriting our political organization like a magnificent picture now fading with age, not only neglected to restore its original colours but did not even bother to ensure that it retained its basic form and, as it were,

${ }^{84}$ J.E.G. Zetzel, 'Natural Law and Poetic Justice: A Carneadean Debate in Cicero and Virgil' (1996) 91 Classical Philology 297, 311.

85 Plato, n 19 above, VI, 16.

86 Zetzel, n 84 above, 310.

87 Piny the Elder Natural History (in J. Healy (ed), London: Penguin, 2004), 3.5.39.

88 De architectura, (in R. Schofield (ed), London: Penguin, 2007). See also the anonymous author known as Aetheticus writing in the late fourth or early fifth century: '[T]hat the Senate and People of Rome, masters of the whole world, conquerors and rulers of the globe, at the time when their triumphs reached everything that lies under heaven [...] having subjugated the world by their prowess, marked everything with their own boundary, wherever the earth extends. And lest anything should escape their divine mind, which is master of all things, they traced out what they had conquered according to the four cardinal points of the sky, and by their celestial wisdom announced that everything that is surrounded by ocean consists of three parts, meaning Asia, Europe and Africa.' I.K. McEwen, Vitruvius: Writing the Body of Architecture (Cambridge, Mass: MIT Press, 2004). 
its faintest outlines. ${ }^{89}$ And within a handful of years, the Republic constitution with whose protection Cicero's career was bound, collapsed for good. The maelstrom leading to that final collapse took Cicero with it, the victim of what was in effect political murder, having been proscribed as an enemy of the State with the rise of the second triumvirate.

\section{PROPORTIONALITY, LAW, AND JUSTICE IN CLASSICAL THOUGHT}

Plato and Cicero present contrasting theories of law and politics. But, in both, proportionality lies at the heart of a dense set of relations, imbricated in a theory of distribution, a theory of justice, a theory of the city or state, a theory of social and political order, and ultimately a theory (or metaphysics) of cosmic harmony. More pertinently for our story, proportionality in both accounts is not just a central feature of a theory of justice, but is presented also as a matter of public law, a governing principle of legal and constitutional arrangements within the state.

There are number of features of this classical conception that are worth highlighting. Interesting in their own right, they also have capacity to shed light on versions of proportionality that are now in currency. One feature is what we might call the 'rounding off' of proportionality. (The question here is 'proportionate in relation to what?') Proportionality in both Plato and Cicero is understood as a kind of a good in itself. There is something good - certainly something beautiful - in the very idea of things being properly aligned. But proportionality's real value derives from the way it integrates and balances an order of values to which it is both somehow extrinsic and intrinsic. Proportionality, then, is (largely) a relational and aesthetic concept. Its importance (and virtue) stems ultimately from the way it glues together other values or orders of value. It is 'rounded off' in relation to those values. This rounding off process can be expressed in different ways. Plato often talks in terms of 'right measure', where the measure in question is a set of mathematical equations (or are expressible in such terms), mathematics and geometry being understood as both expressions of and ways of capturing the harmonious order of the cosmos. In Cicero, 'proportionate equality' relates to a scale of dignitas, which equates principally to currently existing material status, and especially property holding, and thereby to the solidification of the divinely modelled republic of laws.

Proportionality stabilises and sanctions a normative frame. But, whatever they are, the elements that together make up that frame must themselves be good (or have the potential to be good) from the start. It is the combination of such elements in the right order that gives legitimacy to a constitutional order. Proportionality is what makes the elements combine virtuously - or else is the term that describes the condition in which they have so combined. Proportionality describes an arrangement that works on a number of interrelated levels, the proportionate arrangement of each level being connected to the proportionate arrangement of the others. Things are in proportion when things from top to bottom line up in the way that they should. When this does occur, we have found the Platonic equation of harmonious soul, harmonious city, and harmonious cosmos. The heavenly bodies are in alignment with themselves

${ }^{89}$ Plato, n 19 above, V, 2. 
and also with the ideal city. The inhabitants of the city are at one with themselves and also with the soul of each inhabitant. And the individual soul, situated in the good city and aping the movement of the stars, exists in balance with itself and the body.

A second noteworthy feature of the classical conception relates to what we might call the 'reaching out' of proportionality. (The question here is 'proportionate in relation to whom?') Both Plato and Cicero pay special attention to the particular environment in which their theory of proportionate justice plays out. Proportionality works more in the concrete than the abstract. It is a situated concept. It is about justice and law in a particular place, whether that place is Plato's (near-)ideal city, arranged and ordered with a degree of specificity bordering on the obsessive-compulsive, or the Ciceronian vision of the Roman republic or 'Roman cosmopolis'. The attention that each author gives to the jurisdiction in which proportionality plays out is by no means incidental. Plato is clear that significant deviation from the conditions that operate in Magnesia will mean that it is impossible for the city to become virtuous. Cicero writes about the Roman constitution precisely because it conforms most closely to the dictates of natural law. Other constitutions are deficient in the manner in which their arrangements correspond to the requirements of balance and proportionate equality. The strong claims for integration and unity that underlie the use of proportionality in both accounts drive the theorist to consider what the limits of the relevant community might be. This is clearest in Cicero's writings, since it is clear that he struggled on this score. It is one thing to say (with Plato) that proportionate justice applies only to a strictly limited number of inhabitants of a particular polis. It is quite another to suggest, as Cicero was inclined to do, that the relevant class is humankind in general and that proportionality must have a global reach. In either case, to talk about proportionality presupposes talk about the jurisdiction in which it is meant to operate.

\section{PROPORTIONALITY AND THE COMMON LAW WORLD}

Enough has been said already, I hope, to hint at an alternative history of proportionality. Proportionality has a lineage far older and more distinguished that the German principle of Verbälnismässigkeit. The classical sources discussed here provide support not only for the facile proposition that the proportionality principle has roots in older theories of justice. They also support the more serious claim for an older genealogy of proportionality as a matter of public law. No doubt a direct link can be found between ancient and modern. Given that the foundations of German law lie in the ius civile, the 'original' German principle was itself most likely influenced by classical sources generally and by Roman law more specifically. ${ }^{90}$ But, whatever the extent of such a link, uncovering the classical account of proportionality reveals a deeper stratum beneath the principle in its current manifestation.

${ }^{90}$ E. Engle, 'The History of the General Principle of Proportionality: An Overview' (2011) Willamette Journal of International Law and Dispute Resolution (forthcoming) traces in the barest outline the development of proportionality from Aristotle through Cicero, Aquinas, and Grotius into both German law and the common law. Martin Loughlin traces the German origins of proportionality back to the notion of police - and Polizeinissenschaft as a 'science of right-ordering' - and ultimately to the 'disciplinary revolution' that occurred during the course of the 17th and 18th centuries: see Foundations of Public Law (Oxford: Oxford University Press, 2010), ch 14. 
The classical model of proportionality, expressed with such clarity by Plato and Cicero in their respective variations, offers something of a mirror against which contemporary accounts can be set. One thing that has been touched upon already is what strikes the modern reader as the illiberal and inegalitarian role that proportionality plays in both Plato and Cicero. Proportionality for them was an avowedly aristocratic ideal. Perhaps this should make us pause before assuming too readily that the application of the proportionality principle today will invariably produce liberal outcomes. More substantially, we can see that our notion of proportionality, even in its stronger manifestations, is impoverished when set against classical versions. We will look first at metaphysics and the 'rounding off aspect of proportionality, before turning to its 'reaching out' dimension.

One element missing from our modern accounts of proportionality but fundamental to the classical version is the divine or cosmic. While some commentators go so far as to ascribe to the proportionality principle in the human rights domain a (secularised) religious foundation, ${ }^{91}$ few if any argue that proportionality has a cosmic significance or invoke divine sanction for a favoured construction of legitimate rule. In addition, modern accounts, for all their individualist presumptions, are devoid of any real consideration of what classical authors would have called the soul. One worries that in this silence the individual becomes either an empty cipher, ripe only for the exercise of consumer preferences, or else is constructed juridically by the declaration of rights that proclaims it. ${ }^{92}$ In the latter case, the individual (soul) is equated to what those rights documents say it is.

This is not to say, however, that metaphysical ideas are entirely absent from modern conceptions. Contemporary theories of proportionality, springing from the wreckage of the Second World War, share with their classical forebears a concern to rebalance a world that had fallen so desperately out of kilter. ${ }^{93}$ In this aspiration for salvation we hear an echo of Plato's recourse to proportionality in a time of turmoil and strife during which he saw his once great city suffer defeat and near destruction, and Cicero's deployment of the same idea as his beloved Republic crumbled around him.

The 'rounding off element to proportionality noted in the classical account raises large questions about the application of proportionality in the modern world and the normative framework in which it is meant to operate. Answers to these questions will not be further developed here - other than to note in passing that the post-War development of a 'postpositivist neo-naturalist ${ }^{94}$ legal ethics must form part of the story.

But other points can be made. The first takes us back to where we started. We can now understand many proportionality sceptics' concerns as being about its rounding off aspect. Sceptics often question the capacity of judges to apply proportionality in relation to anything other than rights. ${ }^{95}$ Rights at least provide some normative foundation and steer, they argue, whereas the application of proportionality in other contexts would mean that it would operate

\footnotetext{
${ }^{91}$ See eg M. Perry, The Idea of Human Rights (New York: Oxford University Press, 1998).

${ }^{22}$ See eg C. Douzinas, The End of Human Rights (Oxford: Hart, 2000).

${ }^{93}$ See eg M. Ignatieff, Human Rights as Politics and Idolatry (Princeton: Princeton University Press, 2001).

${ }_{94}^{4}$ Engle, n 90 above, 1.

95 See eg Taggart, n 7 above; J. Adler, 'The Sublime and the Beautiful: Incommensurability and Human Rights' (2006) Public Law 697.
} 
without the guidance of such an established normative framework. And the classical model does indicate that proportionality means almost nothing in itself. I say almost nothing, since it seems that the need for symmetry, balance, and proportional relationships clearly lies deep within the human psyche. ${ }^{96}$ But in general when we talk about proportionality we refer to a relational concept, the virtue of which lies principally in how it glues together other elements and values. Something must be proportionate (or not) in relation to something else. The task of the decision-maker applying proportionality is to identify those elements and values and then to fashion them in a way that produces a harmony of the parts and therefore justice. Now, this task (or at least the first stage of it) might not be too difficult in practice. The values at stake might be obvious. But where they are not, there is a danger that either the judges either would be rudderless or the direction they steered would not have been agreed already by the polity at large. Both problems loom larger for us (perhaps) than for those who articulated the classical model. In part this is because democratic concerns are for us axiomatic in a way they were not for Plato or Cicero. Both rejected democracy as the fundamental political value within the shadow of which their theory of proportionality was to play out. It also may have something to do with the capacity of the ancients - some of them at least - to believe in the determinacy of reason to an extent that is quite breathtaking to the (post-)modern reader. (Although even then, unlike at least some of the moderns, Plato and Aristotle both thought that proportionality was too serious a matter to be contracted out to courts.)

I said earlier that to talk about proportionality is to presuppose a jurisdiction in which it is to operate. Proportionality reaches out, demanding a defined political space in which the balancing is to take place. Currently, in British courts, argument abounds on this score in a way that directly echoes the old Ciceronian tension between locality and globality. Painting with a broad brush, we can identify two general positions: The first, identified in the Human Rights Act's first decade with Lord Bingham, looks outwards, using various international and comparative sources to think through proportionality questions. ${ }^{97}$ The second, represented by Lord Hoffmann, ever more stridently so in his later years on the bench, talks the apparently sturdy language of the English common law, and looks inwards (and backwards) to source its legitimacy. ${ }^{98}$ The debate is particularly pronounced in the UK. Jurisdictional hybrid that the UK now is, British courts are in effect servants of two masters, ${ }^{99}$ with little choice but to strive to identify the source of normative authority - 'European' or 'British' - to which the various parts of the system ought to gravitate. But the tension exhibited in the English cases is also symptomatic of the proportionality debate more generally, at least as that principle plays out in the context of human rights, where it must negotiate a path through the oscillating poles of 'humanity' and 'nation'.

\footnotetext{
${ }^{96}$ See eg R. Wittkower, 'The Changing Concept of Proportion' (1960) 89 Daedalus 199; B. Lepetit, 'Architecture, géographie, histoire: usages de l'echelle' (1993) 13 Genèses 118.

${ }_{97}$ See eg Sir T. Bingham, Widening Horizons: The Influence of International Law and Comparative Law on Domestic Law (Cambridge: CUP, 2010).

98 See eg Lord Hoffmann, 'The Universality of Rights' (2009) 125 LQR 416. See further T. Poole, 'Harnessing the Power of the Past? Lord Hoffmann and the Belmarsh Detainees Case' (2005) 32 Journal of Law and Society 534.

99 At least two masters. The situation is potentially even more complicated in the devolved regions, and especially Scotland.
} 